\title{
불교와 대순사상에 나타난 진묵설화의 차이점 \\ A Study on the Differences between Jinmuk Tales in Buddhism and Daesoon Thought
}

\author{
이 병욱*
}

Lee Byung-wook. Lecturer, Department of Philosophy, Korea University.

\begin{abstract}
In this paper, I will compare the Jinmuk tales from Korean Buddhism and those which appear in Daesoon Thought. Specifically, I will compare the Jinmuk tales from the Jinmukjosayujeokko (震黙柤師遺蹟放, A Study on the Remains of Patriarch Jinmuk) and those from the Jeongyeong (典經), and then study the differences between the two sources. In chapter two, I approach Jinmuk's thought as conveyed in the Jinmukjosayujeokko by examining four points. The first point is that Jinmuk is a transformation-body (an incarnation) of Śākyamuni (釋迦牟尼) Buddha. In the preface of the Jinmukjosayujeokko, Choui (恺衣) says that Jinmuk is a transformation-body of Sākyamuni Buddha. The second point is the spirit of unobstructed action (無礙行), the third point is the spirit of the fundamental congruence between meditative and doctrinal approaches (禪敉一致), and the fourth is the spirit of the fundamental congruence between Confucianism and Buddhism (儒佛 致). In chapter three, I study on the viewpoints which can be derived from Jinmuk tales in Daesoon Thought, and compare the Jinmuk tales from the Jinmukjosayujeokko and the Jeongyeong. The Jinmuk tales from the Jeongyeong can be characterized
\end{abstract}

* 고려대학교 강사, E-mail: lbw33@hanmail.net 
by the Daesoon concepts 'Cheonji Gongsa (天地公事, The Reordering Works of Heaven and Earth)' and 'Haewon Sangsang (解冤相生, The Resolution of Grievances for Mutual Beneficience)'. This is the key difference between the Jinmuk tales from Korean Buddhism and those from Daesoon Thought. If I compare the common subject matter of the Jinmuk tales in the Jinmukjosa yujeokko and the Jeongyeong, the Jinmuk tales from these two sources likewise contain differences. Why do these differences occur? I will explain these differences based on Mircea Eliade's approach to mythology. Eliadian theory posits that myths contain the desires of those who deliver the myths. If I explain the difference between the Jinmuk tales in the Jinmukjosayujeokko and the Jeongyeong based on Eliade's theory, Buddhism has Jinmuk tales composed to reflect Buddhist values, whereas Daesoon Thought has Jinmuk tales composed to reflect the values of Daesoon Thought. As Korean Buddhism and Daesoon Thought promote different values, they thereby have different Jinmuk tales.

Key words: The Jinmukjosayujeokko, The Jeongyeong, Eliadian Theory, Jinmuk as a Transformation-body of Śākyamuni Buddha, Values 


\section{I. 서론}

II. 불교의 진묵설화에 나타난 사상

III. 대순사상에 나타난 진묵설화의 관점과 불교의 진묵설화와의 비교

IV. 결론

\section{I. 서론}

진묵(震默, 1562-1633)은 법호(法號)이고 법명(法名: 法諱)은 일옥 (一玉)이다. 진묵은 7세에 출가해서 전주 봉서사(鳳棲寺)에서 오랫동 안 주석하고 그 후 변산 월명암, 진산 태고사 등에서 수도하였고, 세 간에 많은 이적을 남겼다. 그렇지만 진묵의 이적을 제대로 소개한 글 은 없었는데, 1850년(김기종 서문) 초의(忡衣, 1786 1866)가 편찬한 『진묵조사유적고(震黑祖師遺蹟放)』가 간행되어 비로소 진묵의 여러 이 적이 문서의 형태로 정리되기 시작하였다. 이러한 진묵의 이적은 호남 을 중심으로 민중에서 널리 유행되었는데, 그래서 강증산과 원불교의 소태산에 의해서도 진묵의 이적의 일부분이 채택되었다.

이 글에서는 한국불교와 대순사상의 공통분모의 하나라고 할 수 있는 진묵설화(진묵의 이적)에 대해 검토하고자 한다. 자세히 말하자면, 『진묵 조사유적고』의 진묵설화와『전경』의 진묵설화를 비교하고자 한다. 이 두 책에는 진묵설화라는 공통점이 나타나지만, 동시에 차이점도 보이고 있 다. 그 차이점이 무엇인지 밝히고, 그 차이점이 의미하는 것이 무엇인지 도 아울러 검토하고자 한다.

진묵에 관한 연구가 학계에서 어느 정도 축적되어 있다고 할 수 있다. 
사상적인 측면에 국한해서 살펴보면, 한기두1), 류병덕 외2), 김방륭3), 박윤호4), 차차석5), 원정근6) 등의 연구성과가 있다. 그렇지만, 『진묵조 사유적고』와『전경』에 나타난 진묵설화의 차이점을 밝힌 연구성과는 김 방룡의 「증산교와 진묵도사」 이외에는 없다고 할 수 있다.7) 여기서는 김방룡의 연구성과를 수용하고 나아가 그 지평을 더 확대하고 그 의미 를 부여하고자 한다.

그리고 여기서는 『진묵조사유적고』와『전경』의 진묵설화의 차이점이 의 미하는 것이 무엇인지 검토하기 위해서 종교학의 대가 엘리아데(Mircea Eliade, 1907 1986)의 신화이론을 활용하고자 한다. 물론 신화를 분석하 는 여러 가지 이론이 있지만, 이 두 계열의 진묵설화에 차이점이 생기는 것을 설명하는 데는 엘리아데의 신화이론이 가장 유용하기 때문이다. 여 기서는 엘리아데의 신화이론 가운데서도 신화에는 사실을 전하고자 하는 역사에 대한 저항의식이 있다는 주장에 주목하고자 한다. 이는 신화에는 사실이 아닌 내용이 포함되어 있는데, 그렇다고 해서 신화가 의미 없는

1) 한기두,「진묵의 법풍」, 『한국선사상연구』(서울: 일지사, 1991), pp.610-623.

2) 류병덕• 김홍철 - 양은용, 「호남지역의 진묵신앙 유포현황과 그 민중적 성격」, 『한국 종교』21 (1996): 진묵의 생애와 사상, 진묵의 영향, 진묵신앙의 유포현황에 대해 서술하고 있다. 진묵의 영향으로 진묵신앙과 미륵신앙이 관련이 있으며, 증산교와 원불교에서 진묵신앙을 수용하고 있다고 지적한다.

3) 김방룡, 「증산교와 진묵대사」『신종교연구』4 (2001): 증산사상 체계 안에서 진묵 의 위치, 진묵의 생애와 사상, 증산이 진묵을 불교계 종장으로 삼은 이유에 대해 서 술하고 있다; 김방룡, 「설화를 통해 본 진묵일옥의 삶과 사상, 『한국불교학』 44 (2006): 진묵조사의 생애와 사상, 영향에 대해 서술하고 있다.

4) 박윤호, 「진묵일옥의 선풍 연구」(동국대학교 석사학위 논문, 2008).

5) 차차석, 「진묵일옥의 선사상과 그 연원 고찰」, 『불교연구』 34 (2011).

6) 원정근, 『진묵대사와 조화문명』(대전: 상생출판, 2013): 진묵의 생애와 사상을 서 술하고, 진묵과 증산도의 관계에 대해 밝히고 있다.

7) 김방룡, 「증산교와 진묵대사,『신종교연구』4 (2001), pp.154-157에서『대순전경』 과 『동사열전 의 진묵조사편에 나오는 진묵의 설화, 곧 김봉곡과 진묵이 교류한 내 용을 소개하고, 그 차이점을 밝히고 있다. 진묵의 설화에 차이점이 생기는 것은 증 산이 의도적으로 변형한 것으로 파악하고 있으며, 그 의도는 종교 간의 회통을 통한 조화로운 인간세계 건설에 있었다고 주장한다. 그리고 김명선, 『진묵설화연구』(서 울: 보고사, 2007)에서는 〈진묵이 죽은 이유〉, 〈중태기의 유래〉, 〈진묵과 봉곡의 도력시합>의 3 가지 설화에 대해 여러 가지 변형을 검토하고 있다. 그러나 김명선의 연구는 이 논문에서 분석하려는 주제의식과 일치하지는 않는다. 
것이 아니고, 그 사실이 아닌 부분에 중요한 의미가 담겨있다는 것이다. 신화에서 사실과 다르게 말하는 것에는 기억력의 쇠퇴도 하나의 원인이 되지만, 전달자의 가치관이 투영되는 측면도 있다는 것이다. 이런 점에 착 안하면, 한국불교의 진묵설화와 대순사상의 진묵설화에서 차이점이 생기 는 것도 단순히 기억력의 쇠퇴에 그 원인을 돌릴 것만이 아니고, 한국불 교의 가치관과 대순사상의 가치관이 투영된 결과라고 해석할 수 있는 길 이 열리기 때문이다.

그러면 논지의 전개를 위해서 엘리아데의 신화이론을 김현자의 저서 에 의거해서 간단히 소개한다. 엘리아데는 설화를 크게 2가지로 구분 한다. 하나는 참된 이야기로서 신화이고, 다른 하나는 민담, 전설, 우화 등과 같이 신성성(神聖性)이 없는 이야기다. 참된 이야기로서 신화는 '살아있는 신화'이고, 이 '살아 있는 신화'란 신적(神的) 행위를 모방하 는 것을 의미하고, 신적(神的) 존재가 활동했던 신화적 시간과 공간을 지금 이곳에서 다시 재현하는 것을 의미한다. 그래서 '살아 있는 신화' 는 언제나 종교적 행위를 정당화하는 숭배의례와 관련되어 있고, 이러 할 때 신화는 허구가 아니고 탁월한 진실이 된다.8)

나아가 엘리아데는 역사적 사건이나 인물을 신화적 원형으로 변형 시키는 것 속에서 '역사에 대한 저항의식'을 읽을 수 있다고 주장한다. 1 차세계대전이 일어나기 얼마 전에 루마니아의 민속학자 콘스탄틴 브 레일로우(Constantin Brailoiu)는 루마니아의 마라무레슈라는 마을에 서 비극적 사랑을 내용으로 한 어떤 발라드(중세말기 유럽에서 형성 된 짤막한 이야기 민요체)를 채록하였다.

그 내용은 다음과 같다. 약혼한 한 젊은이가 산의 요정의 마법에 걸 렸다. 결혼을 며칠 앞둔 날 질투에 불탄 요정은 이 젊은이를 높은 바 위 꼭대기에서 떨어뜨렸다. 다음날 목동들이 나무 아래에서 젊은이의 시체와 모자를 발견하고는 마을로 운반해왔다. 그의 약혼녀는 죽은 약

8) 김현자, 『신화, 신들의 역사 인간의 이미지』(서울: 책세상, 2004), pp.288-290. 
혼자 앞에서 신화적 은유로 가득 찬 장송의 비가를 노래하기 시작하였 다는 것이다.

브레일로우는 이 이야기가 언제 일어났는지 마을 사람에게 물어보 았는데, 마을사람들은 아주 오래된 옛날이야기라고 대답하였다. 그렇 지만 좀 더 조사해보니까 겨우 40년 전에 일어난 사건이고, 발라드의 주인공인 약혼자가 아직 살아있었다. 이 약혼자에게 들은 이야기는 평 범한 내용이었다. 그 내용은 다음과 같다. 어느 날 저녁 젊은 약혼자 는 벼랑에서 미끄러졌다. 그는 곧장 죽지 않았고, 그의 비명이 산을 울릴 정도이어서 마을사람들이 마을로 데려왔다. 마을로 운반된 뒤에 이 젊은이는 죽었다. 장례식 때 그의 약혼녀는 마을의 다른 여자들과 함께 통상적으로 하는 비탄을 반복했을 따름이다. 물론 이 비탄에는 산의 요정에 대한 어떠한 암시도 없었다는 것이다.

브레일로우가 이 사실을 마을사람에게 알려주자, 그들은 늙은 여인 이 모두 잊어버렸기 때문이라고 하거나 큰 슬픔이 그녀의 혼을 거의 빼놓았기 때문이라고 대답하였다. 이들에게 진실을 말해주는 것은 신 화였고, 실제의 이야기는 오히려 곡해된 것이다. 엘리아데는 이런 사 실에 기초해서 '신화적 시간 속으로 주기적으로 복귀하는 것'과 '집단 기억 속에 역사성이 없는 점’에는 ‘역사적 시간' 또는 ‘역사적 진실’에 대한 저항이 있다고 한다. 이러한 '역사에 대한 저항'에는 인간의 종 교적 욕구가 있고, 이것이야말로 인간의 존재방식이라고 엘리아데는 주장한다. 이처럼 많은 사람이 바라는 것이 이 신화 속에 투영되었다. 이렇게 보자면, 신화를 통해서 그 신화를 만든 사람의 사고방식을 파 악할 수 있는 길이 열린다.9)

9) 미르치아 엘리아데, 『영원회귀의 신화』, 심재중 옮김 (서울: 이학사, 2003), pp.57-58; 김현자, 앞의 책, pp.301-303. 


\section{II. 불교의 진묵설화에 나타난 사상}

진묵사상에 관한 연구는 앞에서 소개하였지만, 논의의 전개를 위해서 일부 내용을 다시 소개한다. 김방륭은 진묵의 사상을 '(1)선(禪)사상, (2) 진속일여(眞俗一如)의 사상, (3)소요유(逍遙遊) 사상, (4)석가모니의 화 신불, (5) 효(孝)사상'으로 나누어서 설명하였고,10) 원정근은 진묵의 사 상을 (1)석가모니의 화신(진묵대사의 진면목, 대승불교, 소승불교 비판), (2)지극한 효심과 우애, (3) 대장부의 참자유로 구분해서 설명한다.11)

필자는 선행연구성과를 일부분 수용하고 그 바탕 위에 논의를 더 진전시키고자 한다. 여기서는 『진묵조사유적고』에 나타난 진묵의 사상 을 다음의 4 가지로 나누어서 접근한다. 그것은 첫째 석가모니의 화신 불, 둘째 무애행의 정신, 셋째 선교일치의 정신, 넷째 유불일치의 정 신이다. 그러면 순서대로 살펴본다.

\section{1. 석가모니의 화신불}

『진묵조사유적고』의 서문에서 초의는 “우리나라의 진묵대사는 명종 의 시대에 태어났으니 곧 석가모니 부처의 응신(應身: 화신)이다.”라 고 하였다.12) 그리고 또 다른 『진묵조사유적고』의 서문에서 김기종 (金箕鐘)도 진묵대사가 석가모니 부처의 응신이라고 밝히고 있다. “진

10) 김방룡, 「설화를 통해 본 진묵일옥의 삶과 사상」, 『한국불교학』 44 (2006), pp.322333. 그리고 한기두, 「진묵의 법풍」, 『한국선사상연구』(서울: 일지사, 1991), 류병덕· 김홍철 - 양은용, 「호남지역의 진묵신앙 유포현황과 그 민중적 성격」, 김방룡「증산교와 진묵대사, 『신종교연구』 4 (2001)의 내용은 위의 김방룡의 논문(『한국불교학』44)의 내용 속에 포함된다. 류병덕 외의 연구와 김방룡의 연구(『신종교연구 4$)$ 에서는 유교 도교, 불교의 삼교회통사상을 언급하고 있다는 점이 김방륭의 논문(『한국불교학』 44)과 다른 점이다.

11) 원정근, 앞의 책, pp.41-67.

12)『진묵조사유적고』, 『한국불교전서』10권, p.877下, “我東國震默大師 降化於明廟之 世 即釋迦如來應身也." 
묵대사는 여래의 응신으로서 선(禪)과 교(敉)를 수행하였으니 [봉곡선 생과 진묵대사는] 모두 한 시대의 위대한 인물이다."13)

또한 진묵은 사냥꾼들이 소금이 없어서 노루고기의 육회(肉膾)를 먹지 못하는 것을 알고서 시자에게 소금을 보냈는데, 이 일에 감동한 사냥꾼들이 진묵이 사람을 살리는 부처[活人之佛]라고 찬탄하고 있다. 그 자세한 인용문은 다음과 같다.

진묵이 시자를 불러서 봉서사 남쪽에 있는 부곡(婦谷)으로 소 금을 전달하라고 하였다. 시자가 “누구에게 전달합니까?”라고 물었고, [진묵은] “가다보면 마땅히 스스로 알 것이니 어찌 물 을 필요가 있겠는가?”고 하였다. 시자가 소금을 가지고 산봉우 리를 넘어서 계곡으로 내려갔는데, 사낭꾼 몇 사람이 이제 막 노루고기로 육회(肉膾)를 만들어 놓고서 소금이 생각이 나서 [육회를] 먹지 않은 채 앉아있었다. 시자가 그들 앞에 소금을 가져다주니, 모두 기뻐하면서 “이것은 진묵[玉老: 一玉의 노장] 이 우리의 배고픔을 불쌍히 여기는 것이다. 사람을 살리는 부처 가 계곡마다 있다고 하는데, 바로 이 분(진묵)을 말하는 것이 다.”고 말하였다.14)

진묵이 석가모니의 화신불이라는 것은 『진묵조사유적고』의 다른 설 화에서도 나타난다. 진묵이 7세에 출가하였는데, 그는 봉서사에서 옹호 단(擁護壇)에 향을 피우는 소임을 맡았다. 그러자 밀적신장(密迹神將: 부처를 호위하는 신장)이 일을 주관하는 사람의 꿈에 나타나서 “우리 는 부처를 호위하는 신(神)인데, 어떻게 부처에게 예(禮)를 받겠는가 하며, 향을 피우는 소임자를 바꿀 것을 요구하였다.”고 한다.15) 여기서 도 진묵의 석가모니의 화신불이라는 것이 나타난다.

또 청량산(淸凉山) 목부암(木鳥庵)에 있는 16 나한이 항상 진묵과 함께

13) 같은 책, p.876下, “震默大師 以如來應身 修行禪敉 皆一時魁偉之人也.”

14） 같은 책, p.879下, “師喚侍者 送鹽于鳳寺南婦谷中 侍者曰 送與阿誰 日去當自知 何必

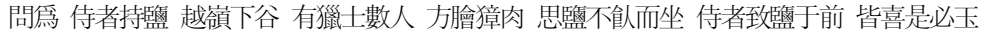
老粼我之創 活人之佛 谷谷有之者 正謂此也.”

15) 이일영 편, 『진묵대사소전』(서울: 보림사, 1983), p.44. 
있으면서 시봉하였다는 내용도 있다.16) 나한이 진묵을 시봉하였다는 것 은 바로 진묵이 화신불이라는 것을 의미하는 것이다. 또 진묵이 한 사미 (沙彌)와 함께 길을 갔는데, 이 사미는 가볍게 물을 건넜는데, 진묵은 그 만 물에 빠지고 말았다. 이 때 진묵은 이 사미가 나한이고, 나한의 장난 에 빠졌다는 것을 알고서, 나한에게 대도(大道)를 알지 못한다고 꾸짖는 게송을 지었다. 여기서도 나한을 꾸짖는 것을 미루어 볼 때 진묵의 나한 그 이상의 존재(화신불)라는 것을 시사한다. ${ }^{17)}$

또한 대둔사(大芒寺)의 어느 승려가 대원사(大元寺: 大院寺)에 있는 진 묵에게 신력(神力)에 의해서 4 년 동안 공양을 드렸고, 진묵은 대원사의 여러 승려에게 “대둔사는 7대 동안 액운을 당할 것이다.”라고 하였다.18) 또 1622년에 전주부(全州府)의 송광사(松廣寺)와 홍산(鴻山)의 무량사(無 量寺)에서 진묵을 불상을 만드는 데 증명법사로 모셨는데, 진묵은 직접 가지 않고 주장자와 염주를 보내어서 증명법사의 역할을 하도록 하였다. 그런데 무위사의 화주승(化主僧)이 진묵의 당부를 어기자 갑사(甲士: 갑 옷을 입은 병사)의 처벌을 받았다는 내용이 있다.19) 여기서는 진묵이 신 이한 존재라는 것을 보여주는데, 불교의 맥락으로 보자면, 이런 신이한 일이 생긴다는 것은 진묵이 부처, 곧 화신불임을 보여주는 것이다.

그리고 대원사의 승려가 진묵에게 탁발할 것을 요구하였는데, 진묵 은 다른 승려에게 모여서 공양을 하자고 하고, 시자 기춘(奇春)에게 공 양하려는 승려의 발우들에 바늘 하나를 집어넣도록 하였다. 진묵은 이 바늘이 국수로 변하여 식사를 하였지만, 다른 승려는 그대로 바늘이어 서 공양을 할 수 없었다.20) 이 설화에서는 대원사의 승려들이 진묵이 석가모니의 진신(眞身)임을 알아보지 못했다고 표현하고 있다.

이처럼 진묵의 설화 속에서는 진묵이 화신불이라는 것을 직접적으로

16) 같은 책, p.57.

17) 같은 책, pp.61-62.

18) 같은 책, pp.74-75.

19) 같은 책, pp.77-78.

20) 같은 책, p.46. 
표현하거나 또는 나한에게 명령을 하거나 꾸짖을 수 있는 존재, 또는 신이한 힘을 가진 존재라고 묘사하고 있다. 진묵이 나한에게 명령을 내 릴 수 있는 존재라면 진묵이 부처, 곧 화신불이라는 것을 의미하는 것 이고, 진묵이 신이한 힘을 가지고 있다면, 이는 불교의 맥락에서 읽는 다면 그가 부처, 곧 화신불이라는 것을 나타내는 것이다.

\section{2. 무애행의 정신}

무애행(無礙行)은 겉으로는 불교계율에 어긋나는 것처럼 보이지만, 실제적으로는 불교계율에 부합하는 행위를 말하는 것이다. 다시 말해서 무애행은 외형의 행위는 계율을 어긋나는 것처럼 보여도, 내면의 세계 는 계율에 부합하는 것이다. 『진묵조사유적고』에는 진묵의 무애행이 소 개되어 있다.

진묵은 소년들이 물고기를 잡아서 만든 고기국을 먹었는데, 이는 불 교의 육식을 하지 말라는 계율을 어긴 것이 된다. 왜냐하면, 육식을 하 면 살아 있는 생명을 살생하지 않을 수 없기 때문이다. 그렇지만 진묵 은 물가에서 살아있는 물고기를 다시 배설해내는 신통을 나타내었다. 이는 실제로는 살생을 통해서 만든 고기국을 먹은 것이 아니라 그 물 고기를 살려내 것이 되었다. 이것이 무애행에 속하는 것이다. 그 자세 한 내용은 다음과 같다.

진묵이 길을 가던 차에 많은 소년들을 만났는데, [이들은] 냇 가에서 고기를 잡아서[川獵] 계곡에서 고기를 삶고 있었다. 진 묵이 끓는 솥을 내려다보면서 탄식하며 말하기를 "좋은 물고기 들이 죄 없이 끓는 솥에 삼기는 고통을 당하는구나!”고 하였다. 한 소년이 장난삼아 말하기를 “선사는 물고기국을 먹겠습니까?” 고 하니, 진묵이 “나는 잘 먹지.”라고 하였고, 소년이 큰 그릇 [沙鑼] 을 진묵에게 주고 다 먹도록 하였다. 진묵은 동(銅)으로 된 그릇을 들어서 입에 대고 남기지 않고 한꺼번에 먹었다. 이 에 많은 소년들이 놀라고 괴이하게 생각하면서 말하기를 "부처 는 살생을 경계했는데, 물고기국을 먹다니 어찌 승려다운 처신 
이겠습니까?”고 하였다. 진묵은 “[물고기를] 죽인 것은 내가 한 것이 아니지만, [물고기를] 살리는 것은 나의 몫이다.”고 하고, 마침내 옷을 벗고 물을 등지고 배설하였는데, 헤아릴 수 없이 많은 은빛 비늘의 고기가 항문에서 쏟아져 나왔다. [이 물고기 들이] 살아 움직이는 것이 마치 봄의 물결을 타고 내려가는 것 같았고 [은빛 비늘을] 번쩍이면서 수면위에서 어지럽게 뛰놀았 다. 진묵이 고기를 돌아보면서 말하기를 "사랑스런 고기들아! 이제부터는 멀리 강과 바다에서 노닐면서 먹이를 탐해서 다시 끓는 솥에 삼기는 고통을 당하지 말라.”고 하였다. 이에 많은 소년들이 탄복하고 그물을 거두고 돌아갔다. ${ }^{21)}$

또 진묵은 술이라고 하면 마시지 않고 곡차라고 하면 마셨는데, 이것도 무애행에 포함된다. 무애행은 앞에서 말한 것처럼, 행위의 외형보다 내면 의 세계가 중요한 것인데, 진묵은 외형으로는 술을 마시지만 내면의 세계 에서는 곡차를 마시는 것이다. 그에 관한 설화를 소개하면 다음과 같다.

진묵은 오히려 술 마시기를 좋아했는데, 그런데 곡차라고 하면 마시고 술이라고 말하면 마시지 않았다. 어떤 승려가 연회를 준 비하기 위해서 술을 거르고 있었는데 술향기가 진하게 나서 강렬 한 향기[芳烈]가 사람을 취하게 하였다. 진묵이 주장자를 짚고 가서 묻기를 “그대는 무엇을 거르는가?”하니, 그 승려는 “술을 거릅니다.”라고 하였고, 진묵은 조용히 돌아왔다. 조금 뒤에 [진 묵은] 다시 와서 묻기를 “그대는 무엇을 거르는가?”하니, 그 승 려의 대답은 앞과 같았고, 진묵은 돌아갔다. 잠시 뒤에 [진묵이] 다시 와서 같은 질문을 하니, 그 승려는 끝내 곡차라고 대답하지 않고 또한 술을 내린다고 답하였다. 진묵은 마침내 [곡차를 마실 것이라는] 희망을 버리고 돌아왔다. 그러자 갑자기 금강역사(金 剛力士)가 철봉으로 술을 거르는 승려를 때렸다.22)

21) 『진묵조사유적고』, p.879中-下, “師於路次 值衆少年 川獵 烹鮮于溪邊師俯視沸鼎而 歎曰 好個魚子 無虽而受鑊湯之苦 一少年戯之日 禪師欲沾魚美麼 師日我也善契 少年 日 這一沙鑼 任師盡契 師擡銅沙鑼灌口 頓呷了無餘 於是衆皆驚異日 佛戒殺生能沾魚 美 豈僧也 師曰殺則非我 活之在我 遂解衣背水而䳏之 無數銀鱗從後門潟出 活潑潑如 乘春流而下 閃閃然亂躍水面 師顧謂魚子曰 好個魚子 從今遠游江海 㯖勿領餉而再罹鑊 湯之苦 於是衆少年 歎服解綱而去.”

22) 같은 책, p.878中, “師向喜飲 然謂之穀茶則飲 (句)酒云則不拎 有僧設讌漉酒 酒香爛 發 芳烈醺人 師䲥杖而徃問日 汝漉什麼 僧曰漉酒 師默然而返 俄而又徃問曰 汝漉什麼 僧答之如前 師無聊而返 須果又徃問之如前 僧終不對以穀茶 又答之以下酒 師遂衒望而 


\section{3. 선교일치의 정신}

김기종은 『진묵조사유적고』의 서문에서 진묵이 선(禪)과 교(敎)를 수행했다고 말하고 있다.23) 이러한 내용은 그의 설화에서도 확인된다.

진묵이 월명암(月明庵)에 살았을 때에『능엄경』을 읽었는데, 마침 능엄삼매(首楞三昧)에 들어가서 하루 밤을 보내게 되었다. 그때 바람 때문에 창문이 닫히었고, 그로 인해 진묵의 손가락에 부딪쳐서 피가 났는데도 진묵은 그것도 모른 채 능엄삼매에 들어갔던 것이다. 여기서 그의 선교일치의 정신이 나타난다. 『능엄경(楞嚴經)』은 경전이고 이 경전을 읽는 것은 교(教)에 속하는 것이고, 이 경전을 읽기는 하지만 글자에 집착하는 것이 아니고 삼매(능엄삼매)에 들어간 것은 선(禪)에 속하는 것이다. 이러한 일화 속에서 진묵의 선교일치의 정신이 잘 나 타난다. 이 내용에 대해『진묵조사유적고』에서는 다음과 같이 전한다.

진묵이 일찍이 변산(邊山)의 월명암(月明庵)에서 살았다. 승려 들이 모두 가을의 탁발을 위해서 나갔고 다만 진묵이 시자와 함 께 암자를 지키고 있었다. 그런데 시자에게 기일(롭日)이 있기 때문에 [시자는] 속가로 가야만 하였다. [시자는] 우선 재를 지 내는 음식[齋供]을 마련해서 탁자 위에 두고 [진묵에게] 아뢰기 를 "공양드리는 물품[供具]은 여기에 있으니 때가 되면 스스로 재를 올리세요."라고 하였다. 그 때 진묵은 방장 안에서 창문을 열고 앚아있었다. [진묵은] 손을 문지방에 두고서『능엄경』을 읽었다. 시자가 다음 날 암자로 돌아오니 진묵은 어제의 모습 그대로 앉아있었다. 바람이 불어 문짝이 손가락에 부딪쳐서 피 가 났는데도 [진묵은] 손을 치료할 것을 잊어버리고 경전을 읽 는 것이 평소와 같았다. 그리고 탁자 위의 재를 지내는 음식도 이전처럼 있었고 재를 드리지 않았다. 시자는 절을 드리고 밤 동안의 안부를 물었는데, 진묵은 "너는 제사에 참석하지 않고 빨리 왔구나!”라고 말하였다. [이는 진묵이] 능엄삼매(首楞三昧) 에 들어가서 밤이 이미 지나갔는지도 모르는 것이었다.24)

返 俄有金剛力土 以鐵棒打漉酒僧.”

23) 같은 책, p.876下, “震默大師 以如來應身 修行禪敉.”

24）같은 책, p.878中-下, “師嘗棲于邊山之月明㢆 僧皆秋乞去 惟與侍者看庵 侍者有忌 
앞에서 진묵이 능엄삼매에 들어서 하룻밤이 지나는 것을 몰랐다는 것을 말했는데, 다음의 설화도 비슷한 맥락의 내용이다. 그것은 승려들 이 탁발을 하기 위해 한 달 이상 절을 비웠는데, 그 기간 동안에 진묵 은 선정에 들어서 얼굴에는 거미줄이 쳐있었고 무릎사이에는 먼지가 수북이 쌓여있었다는 것이다. 이 점을『진묵조사유적고』에서는 다음과 같이 말한다.

진묵이 일찍이 상운암(上雲庵)에 주석하였다. 빠른 걸음을 하 는 승려들이 식량을 탁발하기 위해 멀리 나갔다가 한 달이 지나 서 돌아왔다. 진묵의 얼굴에는 거미줄이 쳐있었고 무릎 사이에 는 먼지가 쌓여있었다. 진묵을 위해서 먼지를 털고 거미줄을 제 거하고서 이름을 말하면서 절을 드렸다. 진묵이 “그대들이 돌아 오는 것이 어찌 이렇게 빠른가?”라고 하였다.25)

그리고 진묵은 입적할 때에 선문답의 내용을 주고받았다. 물속에 비 친 그림자를 가리키면서 석가모니 부처의 그림자라고 하였는데, 이는 자신이 곧 부처라는 것이다. 그런데 이것은 자신이 단순히 부처의 화 신이라는 의미라기보다는 자신이 곧 부처라는 것을 깨달았다고 해석해 야 할 것이다. 이는 조동종의 동산양개(洞山良介, 807 869)가 스승 운 암담성(雲嚴量是, 782 841)과 나눈 선문답 내용과 비슷한 점이 있다. 동산이 운암과 작별하면서 묻기를 “스님께서 입적한 뒤에는 사람들이 나에게 '그대는 스승의 진면목을 아직도 생각해낼 수 있는가?'라고 묻 는다면 나는 무엇이라고 답해야 합니까?”하니 운암이 한 동안 잠자코 있다가 “바로 이것이라네.”라고 대답하였다. 동산 여러 곳을 돌아다니 면서 '바로 이것이다’라는 스승의 말을 참구하였다. 뒤에 동산은 냇물 을 건너다가 수면에 비친 자기 모습을 보고 그 자리에서 '바로 이것'의

故 當徃俗家 先判齋供 置諸卓上而啓之日 供具在此 時至自齋 時師在方丈內 推密而坐 以手加䦐 而閱楞瞰經 侍者丞日還庵 師坐如昨日㨾 風戶噬指而血 忘報收手 閱經自若 卓上齋供 依舊不享 侍者展拜問夜候 師曰汝不焦祀 而徑來耶 盖入於首楞三昧 而不知 夜之已經也.”

25）같은 책, p.879下, “師嘗住上雲庵 神足輩以乞糧遠出 月餘乃返 師面上蛛綱 膝間塵 堆 尿之掃塵捜絲 通名拜謁 師曰儞還一何速耶.” 
참뜻을 깨달았다고 한다.26) 동산은 수면에 비친 그림자를 보고 스승의 진면목이자 자신의 진면목을 깨달은 것이고, 진묵은 그것을 석가모니 의 진면목이자 자신의 진면목이라고 표현한 것이다.

그런데 시자는 그 그림자는 진묵의 것이라고 대답하였고, 그러자 진 묵은 그대는 나의 거짓된 몸을 보고 석가모니 부처의 진신(題身)을 보 지 못한다고 말하였다. 다시 말하자면 불교의 진리를 깨달은 사람의 안목에서는 이 육체 그대로 부처의 진신이라는 것을 알 수 있는데, 시 자는 그러한 안목이 없어서 보이는 현상에 집착한다는 것이다. 진묵이 입적할 때의 내용을 더 자세히 소개하면 다음과 같다.

진묵이 어느 날 목욕하고 머리를 깎고[淨髮], 옷을 갈아입고 주장자를 끌며 문을 나섰다. 계곡을 따라 가다가 주장자를 세우 고 물을 마주보면서 서서 손으로 물속의 자기 그림자를 가리키 며 시자에게 말하기를 “이것이 석가모니 부처의 그림자이다.”고 하니, 시자는 "이것은 화상의 그림자입니다."고 하였고, 진묵은 "너는 다만 나의 거짓된 몸[假]을 알 뿐이고 석가모니의 진신 [㐤]을 알지 못한다.”고 말하고는 마침내 주장자를 메고 방에 들어가서 다리를 포개서 결가부좌를 하고 앉아서 제자를 불러 놓고 말하기를 "나는 입적하고자 한다. 너희들이 묻고 싶은 대 로 물어라.”고 하니, 제자는 “화상이 입적한 지 백 년 뒤에는 종승(宗乘)은 누구를 계승한다고 하겠습니까?”고 물었고, 진묵 은 말없이 침묵하였다가 “어떤 종승(宗乘)이 있단 말인가?”라고 말하였다. 제자가 다시 가르침을 달라고 청을 하니, 진묵은 마 지못해서 말하기를 "명리를 추구하는 승려[名利僧]이긴 하지만 청허휴정(淸虛休靜)의 계보에 속한다.”고 하였다. 마침내 편안하 게 입적하니 세속의 나이는 72 세요 법랍은 52 세이니 곧 계유년 (1632) 10월 28일이다.27)

26) 吳經雄, 『선학의 황금시대』, 서돈각·이남영 옮김 (서울: 삼일당, 1978/1983), p.268.

27) 『진묵조사유적고』, p.880上-中, “師一日沐浴 淨髮更衣 曳杖出門 沿溪而行 植杖臨 流而立 以手指水中已影 而示侍者曰 遮個是釋迦佛影子也 侍者日 這是和向影 師曰汝 但知和晌假 不識釋迦眞 遂負杖入室 疊足加跱而坐 召謂弟子曰 吾將逝矣 恣汝所問 弟 子曰 和向百歲後 宗乘嗣誰 師默然良久日 何宗乘之有 弟子再乞 垂示 師不得已而言日 名利僧也 且屬靜老長 遂怡然順宗 世壽七十二(㲘記)(中有此三字)法臘五十二 即癸西十 月二十八日也.” 


\section{4. 유불일치의 정신}

『진묵조사유적고서』에서 김기종은 진묵이 불교의 승려이지만, 유교의 행실을 갖추고 있다고 평가하고 있다. 그러면서 진묵이 봉곡선생과 교 류하였고(이 부분은 뒤에 서술할 예정임), 진묵이 입적했을 때 봉곡선 생이 애도하였다는 점을 소개하고 있다.

봉곡선생이 [진묵이 입적했다는 소식을] 듣고 탄식하며 말하 기를 “이 승려는 이름이 불교이지만 행실은 유교였다.”고 하며 슬픔을 이기지 못하였다. [다음은 김기종의 말이다] 오호라! 승 려 가운데 유교의 행을 갖춘 사람이 거의 드물지만, 진묵은 이 것[불교와 유교]을 겸하였다. 그러므로 진묵이 생존했을 때에는 [봉곡선생이] 함께 교류하였고, 진묵이 입적했을 때에는 [봉곡 선생이] 그를 위해서 [앞에 소개한 것처럼] 애도하였으니, 봉곡 선생의 한 마디 말의 무거움은 오히려 진묵의 명성을 길게 남 기는 것이구나.28)

진묵은 출가하였지만, 자신이 머무는 절 근처에 노모를 모시고 봉양 하였고, 어느 여름철에 노모가 모기로 인해 고생을 하자 산신령에게 부 탁을 해서 모기를 내쫓았다고 한다. 또한 진묵이 어머니의 장례 때에 지은 제문에는 간절한 효심이 잘 나타나 있다. 이러한 효심은 진묵이 출가한 승려이지만, 유교의 가르침에도 관심을 가지고 실천했음을 보여 주는 예이다. 『진묵조사유적고』에서는 다음과 같은 내용을 전한다.

진묵은 왜막촌(倭幕村)에서 노모를 봉양하면서 자신은 왜막촌 뒤에 있는 일출암(日出庵)에 머물렀다. 여름철에 [진묵의] 어머 니가 모기 때문에 고생을 하자, 진묵은 산신령에게 부탁을 해서 모기를 내쫓았다. 그 후로 지금까지 그 한 마을(왜막촌)에서는 모기로 인한 고통이 없다고 한다. [진묵의] 어머니가 돌아가자, 제사를 지냈는데 그 제문(祭文)에서 다음과 같이 말하였다. “태

28）같은 책, p.877上, “先生聞而歏曰 此僧墨名而儒行 不勝腫州 噫 僧而有儒行者幾希

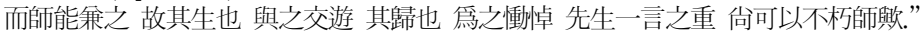


(胎)중에서 10개월 있었던 은혜 무엇으로 보답하겠는가? 무릎 아래에서 3년 동안 길러준 것을 아직 잊을 수 없도다! 만 세 위 에 다시 만 세를 추가해도 자식의 마음으로는 오히려 부족하거 늘, 백 년의 인생에서 백 년조차도 다 채우지 못했으니 어머니 의 수명이 어찌 그리도 짧습니까? 하나의 표주박으로 길 위에서 탁발하는 이 승려는 이미 말할 것도 없고, 비녀 꽂고 규중(䦙中) 에서 아직 결혼하지 못한 어린 여동생이 어찌 슬퍼하지 않겠습 니까? 제단(祭壇)에 오르고 그리고 제단에 내려와서 [제사를] 마치고는 승려들은 각자의 방으로 찾아가고, 앞산과 뒷산은 첩 첩히 쌓여있으니, [어머니의] 혼백은 어느 곳에 돌아가렵니까? 오호라 슬프구나!" 그리고 나서 [진묵은] 만경(萬頃)의 북쪽에 있는 유앙산(維仰山: 일명 祖仰山 또는 行舟山)29)에 돌아가서 장례를 치렀는데, [그 산소를] 청소하고 [술을] 붓는 사람은 번 번이 농사가 잘되었다. 그래서 근처의 마음사람과 먼 곳의 마을 사람이 뒤질 것을 두려워하며 앞을 다투어 [산소에 예를 드렸 고] 지금까지 수백 년 동안 제단의 영역[封域]이 분명하고, 향 불[香火]이 끊어지지 않았다고 한다.30)

\section{III. 대순사상에 나타난 진묵설화의 관점과 불교의 진묵설화와의 비교}

앞에서『진묵조사유적고』의 진묵설화에 나타난 사상을 살펴보았는데, 그것은 화신불, 무애행, 선교일치의 정신, 유불일치의 정신으로 정리된 다. 여기서 가장 중요한 것은 진묵은 화신불, 곧 부처가 세상에 몸을 나타낸 존재라는 것이다. 대순사상에서는 진묵설화는 천지공사와 해원

29) 이일영 편, 앞의 책, p.25.

30)『진묵조사유적고』, p.878上-中, “奉養老母於倭幕村(全州地) 師居村後之日出庵 夏日 母以蚊子䈆苦 師屬山靈而歐蚊 自後至今 一村說無蚊子之苦 及夫母歿 祭之 以文日 胎 中十月之恩 何以報也 㯟下三年之養 未能忘矣 萬歲上更加萬歲子之心 猶爲嫌焉 百年 內未滿百年 母之壽何其短也 單漂路上 行之一僧 覞云已矣 横釵閏中未婚小妹 寧不袁 哉 上壇了 下壇罷 僧尋各房 前山疊 後山重 魂歸何處 鳴呼哀哉 云歸葬於萬頃北面之 維仰山 而有掃除侑者 軴得農故 遠近村人 爭先恐後 至今數百年 封域宛在 香火不絕.” 
상생에 활용된다. 이것이 『진묵조사유적고』의 진묵설화의 사상적 내용 과 가장 큰 다른 점이다.

이러한 다른 점은 『진묵조사유적고』와『전경』에서 같은 주제의 진묵설 화 속에서 다른 점이 등장하게 하는 근거가 된다. 김봉곡과 진묵이 서로 교류하는 내용이『진묵조사유적고』와『전경』에 소개되는데, 『진묵조사유적 고』에서는 이 둘의 관계가 나쁘지 않은 것으로 묘사되지만, 『전경』에서는 이 둘의 관계가 나쁜 것으로 묘사된다.

또 전주에 사는 한 아전이 진묵에게 도움을 청해서 곤란한 처지에서 벗 어났다는 내용이『진묵조사유적고』와『전경』에 소개되어 있는데, 『진묵조사 유적고』에서는 진묵이 나한에게 명령을 하는 존재 곧 화신불이라는 점이 나 타나는 데 비해서, 『전경』에서는 북두칠성을 감추는 진묵의 신이한 능력이 강조되고, 진묵이 화신불이라고 묘사되지 않는다.

\section{1. 대순사상의 진묵설화에 대한 관점}

『전경』에서는 이 화신불의 이미지를 수용해서 진묵을 불교의 종장 (宗長)으로 삼는다. 이는 진묵이 불교계를 대표하는 인물이라는 것이다.

또 어느 날 상제께서 말씀하시길「선도(仙道)와 불도(佛道)와 유도(儒道)와 서도(西道)는 세계 각 족속의 문화의 바탕이 되었 나니 이제 최 수운(崔水雲)을 선도(仙道)의 종장(宗長)으로, 진 묵(震黙)을 불교(佛敉)의 종장(宗長)으로, 주 회암(朱晦庵)을 유 교(儒敉)의 종장(宗長)으로, 이마두(利瑪䁇)를 서도(西道)의 종장 (宗長)으로 각각 세우노라」고 하셨도다.

또한『전경』의 다른 대목에서도 진묵이 불교계를 대표하는 인물이라 는 점을 간접적으로 표현한다. 나아가 선도, 불교, 유교의 법술에 차이 점이 있고, 선도가 제일 뛰어나고 그 다음 불교, 마지막이 유교라고 말 하고 있다. 
지나간 임진란을 최 풍헌(崔風憲)이 맡았으면 사흘에 불과하 고, 진묵(震默)이 당하였으면 석 달이 넘지 않고, 송 구봉(宋龜 峰)이 맡았으면 여덟 달에 평란하였으리라. 이것은 다만 선·불 - 유의 법술이 다른 까닭이니라. 옛적에는 판이 좁고 일이 간단 하므로 한 가지만 써도 능히 광란을 바로잡을 수 있었으되 오 늘날은 동서가 교류하여 판이 넓어지고 일이 복잡하여져서 모 든 법을 합하여 쓰지 않고는 혼란을 능히 바로잡지 못하리라.

그리고『전경』에서 진묵의 설화는 천지공사와 해원상생에서 활용되고 있다. 이는 앞에 소개한 『진묵조사유적고』의 내용과는 다른 것이다. 자 세히 말하자면, 진묵은 김봉곡에 의해 몸을 잃게 되어 죽은 뒤에 원(冤) 을 품었는데, 강증산은 이 진묵을 해원시키고 선경(仙境)의 건설, 곧 천 지공사에 활용한다고 말한다. 이 내용에 관한 인용문은 다음과 같다.

상제께서 하루는 종도들에게「진묵(震默)이 천상에 올라가서 온갖 묘법을 배워 내려 인세에 그것을 베풀고자 하였으나 김 봉곡(金鳳谷)에게 참혹히 죽은 후에 원(冤)을 품고 동양의 도통 신(道通神)을 거느리고 서양에 가서 문화 계발에 역사하였나니 라. 이제 그를 해원시켜 고국(故國)으로 데려와서 선경(仙境) 건 설에 역사케 하리라」고 말씀하셨도다.31)

그리고『전경』의 다른 대목에서 강증산이 천지공사를 행했는데, 그것 이 어떤 내용인지 아무도 몰랐는데, 진묵을 초혼(招魂)한 것이라는 주 장도 제기되었다.32) 만약 진묵을 초혼한 것이라면, 여기서도 천지공사 를 하는 데 진묵이 활용된 것이다.

\section{2. '김봉곡과 진묵의 관계'에 관한 설화의 차이점}

『전경』과『진묵조사유적고』에 김봉곡(金鳳谷, 1575 1661)33)과 진

31) 같은 책, 권지 2장 37절.

32) 같은 책, 공사 1 장 15 절. 
묵이 서로 교류한 내용이 소개되어 있다. 그 내용은 대개 비슷하지만, 『전경』과『진묵조사유적고』에서 중요한 차이점은 다음과 같다. 『전경』 에서는 김봉곡이 원래부터 시기심이 많았고 그래서 그는 뛰어난 재주 를 가진 진묵에 대해 시기심을 품었다는 것에 비해서, 『진묵조사유적 고』에서는 김봉곡과 진묵의 관계가 나쁘지 않았다는 점이다. 그러면, 먼저『전경』의 내용부터 살펴본다.

상제께서 전주 봉서산(소州鳳棲山) 밑에 계실 때 종도들에게 이야기를 들려주시니라. 김 봉곡(金鳳谷)이 시기심이 강한지라. 진묵(震默)은 하루 봉곡으로부터 성리대전(性理大典)을 빌려 가 면서도 봉곡이 반드시 후회하여 곧 사람을 시켜 찾아가리라 생 각하고 걸으면서 한 권씩 읽고서는 길가에 버리니 사원동(寺院 洞) 입구에서 모두 버리게 되니라. 봉곡은 과연 그 책자를 빌려 주고 진묵이 불법을 통달한 자이고 만일 유도(儒道)까지 통달하 면 상대할 수 없게 될 것이고 또 불법을 크게 행할 것을 시기 하여 그 책을 도로 찾아오라고 급히 사람을 보냈도다. 그 하인 이 길가에 이따금 버려진 책 한 권씩을 주워 가다가 사원동 입 구에서 마지막 권을 주워 돌아가니라. 그 후에 진묵이 봉곡을 찾아가니 봉곡이 빌린 책을 도로 달라고 하는지라. 그 말을 듣 고 진묵이 그 글이 쓸모가 없어 길가에 다 버렸다고 대꾸하니 봉곡이 노발대발하는도다. 진묵은 내가 외울 터이니 기록하라고 말하고 잇달아 한 편을 모두 읽는도다. 그것이 한 자도 틀리지 않으니 봉곡은 더욱더 시기하였도다. ${ }^{34)}$

『진묵조사유적고』에도 앞에 언급한 내용과 비슷한 내용이 소개되어 있다. 그렇지만 앞에 소개한 『전경』의 내용에서는 김봉곡의 시기심이 강조되고 있지만, 여기서는 진묵의 능력이 강조되고 있다. 『진묵조사 유적고』에 따르면 진묵은 유교(『강목』35))의 내용도 달통한 인물로 표

33) 김동준(金東準)은 자는 이식(而式)이고 호는 봉곡(鳳谷)이다. 그는 사계(沙溪) 김장 생(金長生)의 제자이다. 인조반정 후에 의금부도사, 사헌부감찰, 한성판관에 임명되 었다. 병자호란(1636) 이후에는 세상을 하직하고 숨어살았다. 황의동, 「진묵대사와 유교의 대화」, 『부처님의 화신 진묵일옥과 봉서사』(제 1 회 진묵조사 사상 학술대회 자료집, 2010), pp.47-49.

34)『전경』, 공사 3 장 14 절. 
현되고 있다. 그 내용을 소개하면 다음과 같다.

[진묵은] 만년에는 항상 봉서사(鳳棲寺)에 머물렀다. 절에서 멀지 않은 곳에 봉곡(鳳谷)선생이 있었는데 [그는] 당시의 유현 (儒賢: 경학에 정통하고 언행이 바른 선비)이었다. [진묵은] 봉 곡선생에게『강목』을 빌렸는데 바랑에 넣고 짊어진 채로 갔다. [이 때] 봉곡선생은 사람을 시켜 [진묵의] 뒤를 따라가서 [동정 을] 살피도록 하였다. [진묵은] 걸어가면서 [책을] 펴서 읽었는 데, [『강목』의] 한 권을 손으로 꺼내서 다 읽고는 땅에 버리고 다시 [『강목』의] 한 권을 꺼내서 [다 읽고는] 땅에 버렸다. 이 와 같이 해서 봉서사의 문에 이르렀을 때에는 [『강목』의 책을] 땅에 모두 버렸는데, [진묵은] 돌아보지도 않고 [봉서사로] 들 어갔다. 다른 날에 봉곡선생이 진묵에게 “책을 빌려서 땅에 버 린 것은 무슨 까닭입니까?”라고 물었다. 진묵은 “고기를 얻었으 면 통발을 잊어버리는 것이요."라고 답하였다. 봉곡선생이 [『강 목』의] 편(篇)마다 어려운 대목을 거론하였는데, [진묵은] 환하 게 모두 알고 있었다.36)

그런데『진묵조사유적고』에서는 『전경』의 내용과는 달리 김봉곡과 진묵의 관계가 나쁘게 묘사되어 있지 않다. 이는 앞의 2장 4절 유불일 치의 정신에서 언급하였듯이, 김봉곡은 진묵이 입적하였을 때 애도하 였다는 점에서 확인할 수 있다.37) 또한 김봉곡은 진묵에게 음식을 보 내주었고, 진묵은 김봉곡의 집에 방문하기도 하였다. 『진묵조사유적고』

35) 황의동, 앞의 글, p.47: 『강목』은 주자의『자치통감강목』59권이거나 주자의『성리대 전(性理大全)』70권으로 추정할 수 있는데, 『진묵조사유적고』하권에 실려 있는 『영당 중수기(影堂重修記)』에『강목』 70 권이라고 소개한 것에 주목해서 주자의 『성리대전 이 라고 주장한다. 그리고『대순전경』(1975) 제3장, 147절 pp.162-164에서도『성리대전 이라고 기록되어 있다고 지적한다.

36) 『진묵조사유적고』, p.879上-中, “晚節常住鳳棲寺(全州地) 去寺不遠之地 有鳳谷先生 者 當時儒賢也嘗從先生 借綱目 貯鉢囊 自擔而行 先生使人 隨後覘之 行且披閲 手一 卷 看了拋地 又拢一卷 手之拋之 如是至寺門盡拋 不顧而入 他日先生謂師日 借書而拋 於地何也 師曰得魚者忘鉒 先生逐篇擧難 無不洞悉."

37) 『진묵조사유적고』 하권에 실려 있는 『진묵선사유사발(震默禪師遺事跋) 에는 김봉 곡이 진묵의 입적을 애도한 것이 김봉곡의 『일기』를 통해서 확인된다고 말하고 있 다.(『진묵조사유적고』하권, p.884中) 『진묵선사유사발』은 『진묵조사유적고』의 서문 을 쓴 김기종의 아들 김영곤(金永坤)이 쓴 것이다. 
에서는 진묵의 이미지를 유교의 내용을 통달하고 또한 당시의 뛰어난 유생(김봉곡)에게 대접을 받는 인물로 묘사하고 있다.

어느 날 봉곡 선생이 어린 여종에게 진묵대사에게 반찬을 보 내도록 하였는데, 중간쯤에서 [어린 여종이] 진묵이 허공을 바 라보면서 배회하다가 서있는 것을 보았다. 여종은 진묵의 앞에 서 심부름을 받은 내용을 알렸다. 진묵이 "너는 아이를 낳고자 하는가?”라고 물었고, 여종은 [그 말의 의미를] 알지 못했다. 진 묵이 “그대가 복이 박한 것을 어찌하겠는가? 너는 돌아가서 봉 곡선생에게 내가 갈 것이라고 말하라.”고 말하였다. 여종이 돌아 가서 [그 말을] 전했다. 봉곡선생이 [진묵을] 기다렸는데 이미 도착할 시간인데도 아주 늦게 도착한 것을 이상하게 여겨 물었 다. "어찌해서 오는 것이 늦었습니까?" 진묵이 “우연히 한 조각 의 신령스러운 기운이 있는데, [이것이] 서쪽 끝에서 흘러들어 오고 있었습니다. [이것은] 가장 만나기 어려운 기운이어서 [그 기운에 적합한 사람에게] 넣어주려고 하였는데, 그 만한 사람을 만나지 못했습니다. [이 기운이] 흩어져서 상서롭지 못한 곳으 로 흘러갈 것을 걱정해서 허공 바깥으로 멀리 몰아내었습니다. 그래서 오는 것이 자연히 늦어졌을 따름입니다.”38)

또한 진묵의 대자유의 경지를 노래한 게송(시)이 전하고 있는데, 이 것도 김봉곡과 진묵이 교류할 때 나온 게송일 것이라고 초의는 추정하 고 있다. 이 점에서도 김봉곡과 진묵의 관계가 나쁘지 않았다는 것을 짐작할 수 있다.

진묵이 일찍이 게송을 읋었다. “하늘을 이불 삼고 땅을 자리 로 산을 베개로 삼으며, 달을 촛불로 삼고 구름을 병풍으로 바 다를 술통으로 삼아, 크게 취하여 갑자기 일어나 춤을 추니, 긴 소매에 곤륜산이 걸릴까 하노라." 살피건대(초의의 주석) 진묵 과 봉곡선생이 시(詩)의 운(韻)을 맞추어 시를 지은 것이 많다

38）『진묵조사유적고』, p.879中, “先生一日 令童婢餽饌於師 至中路見師望空徘徊而立 女致命于前 師曰 汝欲生子麼 女不會 師曰奈汝福薄何 汝旋下去 告乃公我來也 女返命 先生待 既至 㤢其太䐅而問日 來何迤 師曰適有一段靈氣 從西極浮來 最是難遇者 要挽 注 不遇其人 卻恐散漫而 流入於不祥之地 故敺而遠屏於空外 故來自遲耳.” 
고 하는데, 세월이 점점 오래되면서 [그 시들이] 흩어져 전해지 는 것이 없으니 애석한 일이다.39)

그렇지만 『전경』에서는 김봉곡과 진묵의 관계는 좋지 않은 것으로 묘사된다. 김봉곡은 진묵이 시해(戸解: 육체에 혼백이 빠져나온 상태) 한 몸을 태워 없애서 진묵이 자신의 몸에 돌아오지 못하게 한다. 그로 인해 진묵은 김봉곡의 후손이 호미를 들고 일을 해야 할 것이라는 일 종의 저주를 하였다. 그 자세한 내용은 다음과 같다.

그 후에 진묵이 상좌에게「내가 八일을 한정하고 시해(戸解) 로써 인도국(印度國)에 가서 범서와 불법을 더 익혀 올 것이니 방문을 여닫지 말라」고 엄하게 이르고 곧 입적(入寂)하니라. 봉 곡이 이 사실을 알고 절에 달려가서 진묵을 찾으니 상좌가 출타 중임을 알리니라. 봉곡이 그럼 방에 찾을 것이 있으니 말하면서 방문을 열려는 것을 상좌가 말렸으나 억지로 방문을 열었도다. 봉곡은 진묵의 상좌에게 「어찌하여 이런 시체를 방에 그대로 두 어 썩게 하느냐. 중은 죽으면 화장하나니라」고 말하면서 마당에 나뭇더미를 쌓아 놓고 화장하니라. 상좌가 울면서 말렸으되 봉 곡은 도리어 꾸짖으며 살 한 점도 남기지 않고 태우느니라. 진 묵이 이것을 알고 돌아와 공중에서 외쳐 말하기를 「너와 나는 아무런 원수진 것이 없음에도 어찌하여 그러느냐.」 상좌가 자기 스님의 소리를 듣고 울기에 봉곡이「저것은 요귀(妖鬼)의 소리 라. 듣지 말고 손가락뼈 한 마디도 남김없이 잘 태워야 하느니 라」고 말하니 진묵이 소리쳐 말하기를 「네가 끝까지 그런다면 너의 자손은 대대로 호미를 면치 못하리라」 하고 동양의 모든 도통신(道通神)을 거느리고 서양으로 옮겨 갔도다. ${ }^{40)}$

이상의 내용을 표로 정리하면 다음과 같다.

39）같은 책, p.879上-中, “師嘗吟偈子曰 天食地席山営枕 月燭雲屏海作樽 大醉居然仍 起舞 却嫌長袖掛崑崙 按師與鳳谷先生 多有唱和者云 而歲月寝久 散漫無傳 惜乎.”

40)『전경』, 공사 3장 15절. 이와 비슷한 진묵설화가 민간에 전승되고 있다. 그렇지만, 이러한 민간전승의 설화와 『전경』의 설화를 비교하는 것은 또 다른 주제에 속하기 에 여기서는 다루지 않는다. 
〈표 1〉

\begin{tabular}{|c|c|}
\hline 『전경』의 내용 & $\begin{array}{l}\text { 김봉곡과 진묵의 관계가 좋지 않았다. 김봉곡은 진묵을 } \\
\text { 시기하였고, 김봉곡은 시해( } \text { •解)한 진묵의 육체를 태워 } \\
\text { 없애서 결국 죽게 만들었다. }\end{array}$ \\
\hline 『진묵조사유적고』의 내용 & $\begin{array}{l}\text { 김봉곡과 진묵의 관계가 나쁘지 않았다. 김봉곡은 진묵 } \\
\text { 에게 음식을 보내기도 하였다. 또한 김봉곡은 진묵이 입 } \\
\text { 적했을 때에 애도하였고(이는 김봉곡의 『일기』에 적혀있 } \\
\text { 었음), 김봉곡과 진묵이 교류할 때 주고받았던 시가 전하 } \\
\text { 고 있다. }\end{array}$ \\
\hline
\end{tabular}

\section{3. '전주에 사는 한 아전의 신이한 체험'에 관한 설화의 차이점}

『진묵조사유적고』와『전경』에서는 전주에 사는 한 아전이 진묵에게 자신의 어려운 사정을 부탁해서 그 일을 해결했다는 내용이 소개되어 있다. 그 내용은 대개 비슷하지만, 『전경』과『진묵조사유적고』에서 중 요한 차이점은 다음과 같다. 『진묵조사유적고』에서는 진묵이 나한에게 명령을 내리는 존재이고 이는 진묵이 부처의 화신이라는 점을 나타내 는 것인 데 비해서, 『전경』에서는 북두칠성을 감추는 진묵의 신이한 힘을 강조하고 있다는 점이다.

우선, 『진묵조사유적고』의 설화에는 진묵이 부처의 화신이라는 개념 이 숨어 있다. 그래서 진묵은 자신이 직접 그 아전의 일을 돕지 않고 나한에게 명령을 내렸고, 나한은 진묵의 명령이기 때문에 어쩔 수 없 이 따른다는 내용이 소개되어 있다. 그 자세한 내용은 다음과 같다.

전주부에 숨어있는 아전이 있었는데, [이 아전이] 평소에 진 묵과 좋은 관계였다. [이 아전은] 수백 량의 관물을 사사롭게 소비하고 장차 도망하고자 하였다. [그는] 진묵에게 와서 말씀 을 드렸는데, 진묵은 “관물을 소비한 것으로 인해 도망하는 것 이 어찌 남아의 일이겠는가? 다만 집에 돌아가서 몇 말의 쌀을 준비하고 다시 이 절에 와서 나한에게 공양하면 장차 좋은 도 
리가 있을 것이다.”고 말하였다. 아전이 [집으로] 가서 [진묵 의] 가르침대로 [쌀을 준비해서] 왔다. 진묵은 시자에게 [아전 이 가지고 온 쌀로] 밥을 만들어서 나한에게 공양하라고 지시 하였다. 그리고 나서 [진묵은] 아전에게 "전주부 가운데에 혹시 비어있는 관직 자리가 있는가?”라고 물었고, [아전이] “감옥의 형리(刑吏) 자리가 비어있는데, [이 자리는] 너무 [수입이] 박 하고 재미도 없습니다.”고 답하였다. 진묵은 “재미없다고 말하 지 말라. 빨리 가서 [형리의 아전을] 맡겠다고 자청하라. 그러 나 30일을 넘지 않기를 바라네.”고 하였다. 아전이 돌아가자 진 묵은 주장자를 가지고 나한당에 들어가서 나한의 머리를 순서 대로 3번 때리고서 말하기를 "모 아전의 일을 잘 돕도록 하라." 고 하였다. 다음 날 밤에 나한이 그 아전의 꿈에 나타나서 꾸짖 으며 말하기를 “네가 구하는 것이 있으면 마땅히 우리(나한)에 게 곧장 와서 말할 것이지 어찌 진묵대사에게 부탁해서 우리를 수고롭게 하는가? 너의 소행으로는 들어주지 않을 것이 옳은 것이지만 진묵대사의 명령이니 따르지 않을 수 없다. 그러므로 지금은 너의 일을 봐주기는 하지만 후에는 이러한 일이 없도록 하라."고 하였다. [이에] 아전이 [나한의] 도움이 있을 줄 알고 감옥의 관리가 될 것을 자청하였다. 얼마 지나지 않아서 감옥의 송사가 많이 생겨서 죄인이 감옥에 가득 차서 [감옥의 관리가 된지] 30일 안에 부족한 관물을 다 채우게 되어 다른 관리에게 자리(감옥의 관리)를 양보하였다. 얼마 지나지 않아서 새 감옥 의 관리는 뇌물을 요구한 죄로 체포되었다.41)

그에 비해, 『전경』에서는 앞에 소개한 것과 같은 주제의 내용을 전하 고 있지만, 강조하는 점이 다르다. 『전경』에서는 진묵이 북두칠성을 7일 만에 모두 숨겨서 나라에서 사면령을 내리게 했다는 신이한 능력을 강 조하고 있다. 한편, 『진묵조사유적고』에서는 진묵이 나한에게 명령을 내

41) 『진묵조사유적고』, pp.878下-879上, “全州府有一隱吏者 素與師善 以欠逋數百 而 將欲逃之 來辭於師 師曰負逋逃走 豈男兒事 但歸家判數斗米 却來這裏 供養羅漢 將有 好道理 史去 依敎而來 師命侍者炊饭 供養羅漢 因謂吏日 府中有或閶窠麼 日有獄刑吏 作關 而甚薄無聊 師日勿謂無聊 亟徃自請爲之 而幸無過三十日 吏去 師寺柱杖 入羅漢 堂 次第打羅漢頭三下日 某吏事善助之 柆夜羅漢現於吏夢 而責之日 儞有所求 當直就 我輩而言之 何以杆扣於師傳而致苦我耶 以汝則不顧可矣 師傳之命 不可不遵故 今視汝

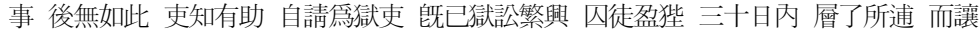
任於他吏 未幾 新吏 拘於徵衉之罪.” 
리는 존재, 곧 부처의 화신이라는 점을 나타내고 있다. 『전경』의 내용을 소개하면 다음과 같다.

김 형렬은 상제를 모시고 있던 어느 날 상제께 진묵(震黑)의 옛일을 아뢰었도다.「전주부중(소州府中)에 한 가난한 아전이 진 묵과 친한 사이로서 하루는 진묵에게 가난을 벗어나는 방법을 물으니 진묵이 사옥소리(司獄小吏)가 되라고 일러주니 아전은 이는 적은 직책이라 얻기가 쉬운 것이라고 말하고 자리를 떠났 으나 그 후에 아전은 옥리가 되어 당시에 갇힌 관내의 부호들을 극력으로 보살펴주었나이다. 그들은 크게 감동하여 출옥한 후에 옥리에게 물자로써 보답하였다 하나이다. 그리고 진묵은 밤마다 북두칠성을 하나씩 그 빛을 가두어 사람들에게 보이지 않게 하 여 七일 만에 모두 숨겨버렸다 하나이다. 태사관(太史官)이 이 변은 하늘이 재앙을 내리심이니 천하에 대사령을 내리시어 옥문 을 열고 천의에 순종하사이다 하고 조정에 아뢰오니 조정은 그 것이 옳음을 알고 대사령을 내렸다 하나이다.」

이 말을 상제께서 들으시고 말씀하시기를 「진실로 그러하였 으리라. 내가 이를 본받아 한 달 동안 칠성을 숨겨서 세상 사람 들의 발견을 시험하리라」 하시고 그날 밤부터 한 달 동안 칠성 을 다 숨기시니 세상에서 칠성을 발견하는 자가 없었도다. ${ }^{42)}$

이상의 내용을 표로 정리하면 다음과 같다.

〈표 2〉

\begin{tabular}{|c|l|}
\hline 『진묵조사유적고』의 내용 & $\begin{array}{l}\text { 진묵은 나한에게 명령을 내리는 존재이다. 이는 진묵 } \\
\text { 이 부처의 화신이라는 것을 나타내는 것이다. }\end{array}$ \\
\hline 『전경』의 내용 & $\begin{array}{l}\text { 북두칠성을 감추는 진묵의 신이한 능력이 강조된다. } \\
\text { 나한에게 명령을 내리는 측면은 나타나지 않는다. }\end{array}$ \\
\hline
\end{tabular}

42)『전경』, 행록 1장 31절. 


\section{IV. 결론}

이 글에서는 『진묵조사유적고』와『전경』의 진묵설화의 차이점에 대 해서 살펴보았다. 이제 그 내용을 차이점이 의미하는 것이 무엇인지 알아보고자 한다.

2장에서는 『진묵조사유적고』에 나타난 진묵의 사상을 검토하였다. 선행연구성과를 일부 수용하고 그 위에 필자의 견해를 새롭게 추가한 다. 그래서 진묵의 사상은 다음의 4 가지 항목으로 구분한다. 첫째, 석 가모니 화신불이다. 『진묵조사유적고』의 서문에서 초의는 진묵은 석가 모니의 응신(화신)이라고 하였고, 이러한 내용은 진묵이 나한에게 명 령을 내리거나 또는 나한을 꾸짖거나 하는 내용, 또는 진묵의 신이한 이적에서 직접적 또는 간접적으로 추론된다.

둘째, 무애행의 정신이다. 무애행은 외형적으로는 계율을 어긴 것처 럼 보이는 행위를 하지만, 실제적으로는 계율의 정신에 부합하는 것이 다. 진묵은 소년들이 권하는 고깃국을 먹었는데, 이는 살생의 계율을 어긴 것이다. 왜냐하면 육식을 하기 위해서는 살생을 하지 않을 수 없 기 때문이다. 그런데 진묵은 육식을 하였지만, 곧 바로 항문으로 살아 있는 물고기를 배설하였다. 이는 겉으로는 육식을 해서 살생을 방조한 셈이 되었지만, 실제적으로는 물고기를 살려낸 것이고, 그래서 무애행 에 속하는 것이다. 이는 진묵이 술을 마신 설화에서도 마찬가지다.

셋째, 선교일치의 정신이다. 『진묵조사유적고』의 서문에서 김기종은 진묵이 선(禪)과 교(敉)를 수행했다고 말한다. 이는 진묵이『능엄경』을 읽으면서 능엄삼매에 들어갔다는 점에서 확인할 수 있다. 『능엄경』을 읽는 것은 경전을 읽는 것이므로 교(敎)에 속하고, 그렇지만 삼매에 들어갔으므로 이것은 선(禪)에 속한다고 할 수 있다. 그리고 진묵의 선사상은 진묵이 자신의 물속에 비친 그림자를 석가모니의 그림자라 고 말한 것에서 확인할 수 있다. 이는 자신이 화신불이라는 것을 말했 
다고 해석하기보다는 자신이 그대로 부처라는 것을 깨달았다고 해석 하는 것이 순리라고 생각한다.

넷째, 유불일치의 정신이다. 김기종은 『진묵조사유적고』의 서문에서 진묵이 불교의 승려이지만 유교의 행실을 갖추었다고 평가한다. 그리 고 이는 진묵이 자신이 머무는 절 근처에 노모를 봉양하고 노모를 위 해서 산신령에게 부탁해서 모기를 몰아내었다는 설화에서 확인된다. 이 설화에서 진묵의 효심(孝心)을 확인할 수 있고, 이 효심은 진묵이 그의 어머니 장례 때에 지은 제문(祭文)에서 잘 나타난다.

3 장에서는 『전경』에 나타난 진묵설화의 관점을 살펴보고, 『진묵조사 유적고』와『전경』에서 공통된 주제의 진묵설화에 어떠한 차이점이 있는 지 알아보았다. 우선, 『전경』의 진묵설화에서는 진묵을 천지공사와 해 원상생에 활용하는데, 이것이 바로 대순사상의 진묵설화에 대한 관점이 다. 앞에서『진묵조사유적고』에 나타난 진묵의 사상을 4 가지로 정리했 는데, 가장 중요한 것은 진묵이 화신불이라는 것이고, 이것이 『전경』에 수용되어 진묵은 불교계를 대표하는 종장(宗長)으로 자리매김 된다.

이러한 『전경』의 관점은 동일한 주제의 진묵설화라도 『진묵조사유 적고』와『전경』에서 다르게 표현되는 근거가 된다. 진묵과 김봉곡은 서로 교류하였는데, 『진묵조사유적고』에서는 진묵과 김봉곡의 사이가 나쁘지 않은 것으로 표현되어 있다. 그래서 김봉곡은 진묵이 입적하였 을 때 애도하였고, 진묵과 김봉곡이 서로 시를 짓기도 하였다고 한다. 그에 비해, 『전경』에서는 김봉곡이 진묵을 시기하였고, 그래서 진묵의 육체를 불태워서 결국 진묵을 죽게 만든다. 『전경』에서는 이로 인해 진묵이 한(恨)을 품었고, 강증산은 진묵의 한(恨)을 풀어주고 선경(仙 境)을 건설하는 데 참여하도록 한다.

또 전주에 사는 한 아전이 진묵에게 부탁해서 어려운 처지에서 벗 어난 내용이『진묵조사유적고』와『전경』에 소개되어 있는데, 구체적으 로 들어가면 강조하는 점이 다르다. 『진묵조사유적고』에서는 진묵이 나한에게 명령을 내리는 존재이고 이는 진묵이 화신불이라는 것을 나 타내는 것이다. 그에 비해, 『전경』에서는 북두칠성을 감추는 진묵의 
신이한 능력이 강조되고 있고, 강증산은 진묵의 신이한 능력을 넘어서 는 더 큰 신이한 능력이 있다고 말하고 있다. 『전경』에서는 진묵보다 강증산이 더 뛰어난 존재라는 것을 나타내고 있다.

그러면 『진묵조사유적고』와『전경』에서 진묵의 설화라는 공통분모 가 있지만, 또한 이러한 차이점이 나타나는 이유가 무엇일까? 필자는 그 이유를 밝히기 위해서 엘리아데의 신화이론을 빌리고자 한다. 엘리 아데는 신화를 '살아있는 신화'와 '신성성이 없는 신화'로 구분하고, '살아있는 신화'에 의미를 둔다. 또 그는 신화에는 '역사에 저항하는 의식'이 있다고 지적한다. 신화에는 역사적 사실과 다른 부분이 포함 되어 있는데, 이는 단순히 민간기억의 감퇴로 인한 것만이 아니고 신 화의 전달자의 가치관이 투영된 측면이 있다는 것이다. 그러므로 엘리 아데의 신화이론에 따르면, 신화는 신화를 전달하는 사람의 희망사항 이 투영된 것이라고 할 수 있다.

이 엘리아데 신화이론을 통해서『진묵조사유적고』와『전경』에서 진묵 설화의 차이점이 생기는 것을 설명할 수 있다고 생각한다. 불교계의 『진 묵조사유적고』에서는 불교의 가치관(석가모니 화신불, 무애행의 정신, 선 교일치의 정신, 유불일치의 정신)이 투영된 진묵설화가 전승되었고, 대순 사상의『전경』에서는 대순사상의 가치관(천지공사와 해원상생)이 반영된 진묵설화가 전승되었다. 그렇기 때문에 진묵설화라는 공통점이 있지만, 동시에 강조하고자 내용에서 서로 차이점이 생길 수밖에 없는 것이다.

끝으로, 이 글에서는 불교와 대순사상에는 진묵설화라는 공통점이 있지만, 또한 동시에 그 진묵설화의 내용에 차이점이 있다는 점을 밝 히고자 하였고, 그를 통해서 거시적으로 볼 때 불교와 대순사상에 진 묵설화라는 공통점이 있지만, 미시적으로 볼 때, 같은 주제내용의 진 묵설화에도 차이점이 있다는 점을 드러내고자 한 것이다. 


\section{【참 고 문 헌 】}

『전경』, 여주: 대순진리회 출판부, 2010.

초의 편, 『진묵조사유적고』, 『한국불교전서』10권, 서울: 동국대출판부, 1989/1997.

이일영 편, 『진묵조사소전』, 서울: 보림사, 1983.

김명선, 『진묵설화연구』, 서울: 보고사, 2007.

김방룡, 「증산교와 진묵대사」『신종교연구』 4, 2001.

「설화를 통해본 진묵일옥의 삶과 사상」, 『한국불교학』 44, 2006.

김현자, 『신화, 신들의 역사 인간의 이미지』, 서울: 책세상, 2004.

더글라스 알렌, 『엘리아데의 신화와 종교』, 유요한 옮김, 서울: 이학사, 2008. 류병덕·김홍철·양은용, 「호남지역의 진묵신앙 유포현황과 그 민중적 성 격」, 『한국종교』21, 1996.

미르치아 엘리아데, 『영원회귀의 신화』, 심재중 옮김, 서울: 이학사, 2003. 박윤호, 「진묵일옥의 선풍연구」, 동국대학교 석사학위 논문, 2008.

원정근, 『진묵대사와 조화문명』, 대전: 상생출판, 2013.

吳經雄, 『선학의 황금시대』, 서돈각• 이남영 옮김, 서울: 삼일당, 1978/1983.

이반 스트렌스키, 『20세기 신화이론』, 이용주 옮김, 서울: 이학사, 2008.

이병욱, 『한권으로 만나는 인도』, 서울: 너울북, 2011/2016.

「한국불교에서 본 대순사상」, 『대순사상논총』 25, 2015.

https://doi.org/10.25050/jdaos.2015.25.1.157

차차석, 「진묵일옥의 선사상과 그 연원 고찰, 『불교연구』 $34,2011$.

한기두, 「진묵의 법풍」, 『한국선사상연구』, 서울: 일지사, 1991.

황의동, 「진묵대사와 유교의 대화」, 『부처님의 화신 진묵일옥과 봉서사』, 제 1 회 진묵조사 사상 학술대회자료집, 봉서사, 2010. 


\section{불교와 대순사상에 나타난 진묵설화의 차이점}

국문요약

이병욱

이 글에서는 한국불교의 진묵설화와 대순사상의 진묵설화를 비교하고자 한 다. 자세히 말하자면, 『진묵조사유적고』와『전경』의 진묵설화를 비교하고 그 차이점에 대해 검토하고자 한다. 2장에서는 『진묵조사유적고』에 나타난 진묵 의 사상을 다음의 4 가지로 나누어서 접근한다. 첫째, 진묵은 석가모니의 화신 불이라는 것이다.『진묵조사유적고』의 서문에서 초의(㞲衣)는 진묵이 석가모니 의 화신이라고 밝히고 있다. 둘째 무애행의 정신이고, 셋째 선교일치의 정신이 며, 넷째 유불일치의 정신이다. 3장에서는 대순사상에 나타난 진묵설화에 관 한 관점을 살펴보고, 『진묵조사유적고』의 진묵설화와 비교한다. 우선 『전경』에 서 진묵의 설화는 천지공사와 해원상생의 관점에서 활용된다. 이것이 불교의 진묵설화와 가장 다른 점이다. 그 다음 진묵설화 가운데『진묵조사유적고』와 『전경』에 공통된 주제를 말하는 것이 있는데, 그 설화들을 비교해보면 역시 차이점이 존재한다. 그러면 이러한 차이점이 생기는 이유는 무엇일까? 여기서 는 엘리아데의 신화이론에 근거해서 설명하고자 한다. 엘리아데는 신화는 그 것을 전달하는 사람의 희망사항이 투영된 것이라고 한다. 이 이론에 근거해서 『진묵조사유적고』와『전경』에 나타난 진묵설화의 차이점을 설명하면, 불교계 의『진묵조사유적고』에는 불교의 가치관이 투영된 진묵설화가 전승되었고, 대 순사상의『전경』에는 대순사상의 가치관이 반영된 진묵설화가 전승되었다고 말할 수 있다. 이처럼 한국불교와 대순사상은 서로의 가치관이 다르기 때문에 같은 주제의 진묵설화라고 해도 전승된 내용에 차이점이 생겼다.

주제어 : 진묵조사유적고, 전경, 엘리아데의 신화이론, 석가모니의 화신불, 가치관 